\title{
Energy Poverty in Turkey
}

Işll Şirin SELÇUK (https://orcid.org/0000-0001-9559-1349), Department of Economics, Bolu Abant İzzet Baysal University, Turkey; e-mail: isilselcuk@ibu.edu.tr

Ali Gökhan GÖLÇEK (https://orcid.org/0000-0002-7948-7688), Department of Public Finance, Niğde Ömer Halisdemir University, Turkey; e-mail: aligokhangolcek@ohu.edu.tr

Altuğ Murat KÖKTAŞ (https://orcid.org/0000-0002-0911-2143), Department of Public Finance, Necmettin Erbakan University, Turkey; e-mail: altugmkoktas@gmail.com

\section{Türkiye'de Enerji Yoksulluğu}

\begin{abstract}
Access to energy is a prerequisite for human development. For this reason, the concept of energy poverty is carefully monitored by the United Nations and the European Union within the scope of "Sustainable Development" objectives. In this study, energy poverty is conceptually investigated, and the data related to the current energy consumption and the main indicators of energy poverty in various countries were examined. Moreover, socioeconomic characteristics of energy poor households in Turkey were examined with the help of the 2017 Household Budget Survey data set. According to the most recent data available, about one-quarter of households in Turkey are energy poor while nearly half of the households, which have the lowest income levels, were found to carry the risk of facing energy poverty. For the richest households, this rate is only $3.48 \%$. Additionally, the share of energy poor households was observed to decrease from 2003 to 2017.
\end{abstract}

Keywords : Energy Poverty, Energy, Turkey.

JEL Classification Codes : $\quad$ Q40, Q48, O12, O13.

\section{$\ddot{\mathbf{O} z}$}

Enerjiye erişim, insani gelişme için bir ön koşuldur. Bu bağlamda, enerji yoksulluğu kavramı "Sürdürülebilir Kalkınma" hedefleri kapsamında, özellikle Birleşmiş Milletler ve Avrupa Birliği tarafından dikkatle izlenmektedir. Çalışmada enerji yoksulluğu kavramsal olarak incelenmiş ve çeşitli ülkelerde mevcut enerji tüketimlerine ilişkin verilere yer verilerek ve enerji yoksulluğu ile ilgili temel göstergeler incelenmiştir. Diğer yandan Türkiye özelinde enerji yoksulu haneler 2017 yılı hanehalkı bütçe anketi veri seti yardımıyla tespit edilerek, enerji yoksulu olarak değerlendirilen hanelerin sosyoekonomik özellikleri incelenmiştir. En güncel veriler olan 2017 yılı hanehalkı verilerine göre Türkiye'de hanelerin yaklaşık dörtte birinin, en düşük gelir seviyesine sahip hanelerin ise yaklaşık yarısının enerji yoksulluğu sorunuyla karşı karşıya olduğu bulunmuştur. En zengin dilimde yer alan hanelerde ise bu oran yalnızca \%3,48 olarak bulunmuştur. Bununla birlikte 2003 yılından 2017 yılına gelindiğinde enerji yoksulu hanelerin oranında azalış tespit edilmiştir.

Anahtar Sözcükler $\quad$ : Enerji Yoksulluğu, Enerji, Türkiye. 


\section{Introduction}

Basically, energy poverty can be described as "not being able to access modern energy facilities." This situation can be noticed not only in developing economies but in developed economies as well and it adversely affects welfare due to such reasons as low energy consumption and pollutive fuel consumption. In this context, energy poverty, as the subject of global interest and policy proposals, is carefully monitored by the European Union and other organizations, particularly the United Nations, within the scope of "Sustainable Development" goals. This issue was considered directly or indirectly in the rounds held in Stockholm (1972), Rio (1992) and New York (2000), and energy poverty was also included in the context of poverty reduction by maintaining development.

17 new global "Sustainable Development Goals" and 169 targets were adopted by the United Nations in New York City on September 25-27, 2015 and the achievement of these goals was aimed by the year 2030. These goals and targets cover a broad range of issues of critical importance for all humanity and the planet throughout the 15 years between 2015-2030. It is stated that new global targets and sustainable development have three dimensions, namely; economic, social and environmental. The goals take numerous areas ranging from starvation to health, from justice to inequality, from global warming to oceans into consideration. Therefore, it is a very inclusive action plan for both the people and the planet. In this context, energy poverty has been pointed out and evaluated within the scope of sustainable development targets with the expression "to ensure universal access to affordable, reliable and modern energy services" in the Goal 7. On the other hand, the UN's non-profit 2018 Sustainable Energy for All initiative, which was launched in 2011 to achieve this goal by 2030, has established three main objectives. These include ensuring universal access to modern energy services, doubling the share of renewable energy in the global energy mix, and doubling the global rate of improvement in global energy efficiency, respectively. In this respect, the UN has designated the year 2012 as "the International Year of Sustainable Energy for All."

According to the International Energy Agency (IEA), access to energy involves a safe and affordable universal access to electricity and clean cooking equipment and electricity. This is sufficient to provide an initial basic energy bundle and then to maintain increased electrical energy over time to reach the regional average. A basic energy bundle includes at least a few bulbs, a flashlight, a phone charge, and a radio. Access to clean cooking facilities means access to modern fuels and technologies (and their primary uses), including natural gas, liquefied petroleum gas (LPG), electricity and biogas (IEA, 2017a: 21).

According to the International Energy Agency, the number of people without access to electricity decreased from 1.7 billion in 2000 to 1.1 billion in 2016 . This decline was due to the expansion of the electricity grid and fossil fuels (45\% coal, 19\% natural gas and $7 \%$ oil). The majority of those who do not have access to electricity are in developing countries of Asia and sub-Saharan Africa. On the country basis, only half a billion people have access to electricity in India alone since 2000. Nonetheless, it is estimated that in India, around 239 
million people in 2016 were without electricity and this figure was almost a quarter of the total number of people without access to electricity worldwide. Other emerging economies in Asia have made a significant breakthrough, and the electrification rate of $67 \%$ in 2000 has reached $89 \%$ as of 2017 . In sub-Saharan Africa, this rate is only $43 \%$. Despite all the progress, $14 \%$ of the world still does not have access to electricity, and $84 \%$ of this population lives in rural areas (IEA, 2017b).

Today, about 2.8 billion people who correspond to $38 \%$ of the global population and about $50 \%$ of the population in developing countries cannot access clean cooking facilities. Upon examining the predictions, it is expected that the rate of access to electricity would be 99\% in developing Asian and Latin American countries by 2030 and 95\% in the Middle Eastern countries according to the 2017 International Energy Agency Report along with a country-based analysis of policies, investments, and technologies. In Sub-Saharan Africa, the rate of access is $59 \%$ in 2030 . However, this progress cannot keep up with the ongoing population growth. Thus, as of $2030,90 \%$ of 674 million people who are still unable to access electricity would be living in sub-Saharan Africa. Nonetheless, all these predictions mean that 674 million people ( $8 \%$ of the world's population) would not have access to electricity as of 2030, with $90 \%$ being in rural areas (IEA, 2017a). According to the EU Revenue and Living Conditions Statistics, 10.2\% of the European population cannot keep their homes warm enough. Other data indicate high levels of energy poverty, particularly in certain parts of Europe, including East-Central Europe and Southern Europe (Rademaekers et al., 2016: 7). Thus, international development organizations often refer to the need to reduce energy poverty primarily in order to reduce poverty (Barnes et al. 2011). In this context, the study tackles the widespread problem of energy poverty. Following the first section in which the studies conducted on energy poverty in the literature are examined, energy poverty analysis is performed for Turkey in the second section.

\section{Conceptual Framework}

Access to energy is, above all, a pre-condition for human development. The wealth and development of a nation are closely linked to the type of transportation and access to energy for its citizens. Therefore, improvement of energy access opportunities is considered as one of the challenges that governments need to tackle.

The complexity of the concept has a negative impact on its definition. Inquiries such as whether or not energy poverty and income poverty have the same meaning, or whether energy poverty should be referred to as access to services such as lighting, cooking, and communication, or to their amount of use have vital importance for a thorough understanding of the issue. In this context, these inquiries raise four different approaches to define energy poverty which can be summarized as follows (Barnes, 2010);

"1. Minimum physical energy requirements for basic needs such as cooking and lighting,

2. Type and amount of energy used at the poverty line, 


\section{Energy consumption which is more than a certain percentage of the total expenditure, \\ 4. Subsisting below a certain level of income, provided that energy use and/or expenditures remain the same in line with the minimum energy demand."}

There is no consensus on the definition of energy poverty in the literature. In the empirical studies conducted on the subject, it is seen that the concept is discussed in different dimensions and this situation affects the methodology. For instance, the energy consumption in the household is compared to household income, and if the threshold amount is exceeded, the household is considered as energy-poor. Energy poverty, which is based on "the basic energy needs" such as lighting, cooking, heating or cooling, which are necessary for the sustainability of daily life, can be explained as the inability or failure to finance those needs. However, energy access which provides information about the socioeconomic status and the structure quality of the household is also closely related to basic services such as health, education, and communication. For example, living in cold houses due to energy poverty increases the risk of death directly, but is particularly harmful to mental health through the material stress it causes (Marmot Review Team, 2011: 23). Thus, there is a frequent relationship between energy and the "Millennium Development Goals." (WB, 2006; Ibitoye, 2013; Nussbaumer, 2012; Modi, 2004).

Although energy poverty and fuel poverty have basic similarities and differences, they are often used as synonyms. The concept of fuel poverty, first introduced in the 1970s, was first coined in the British Parliament in 1977 (HC, 2015) and became an important political issue in the United Kingdom in the early 1980s (Li et al., 2014; Buzar, 2007). Lewis (1982) was concerned with the insufficient heating of households' homes due to financial inadequacy, and Boardman (1991) defined fuel poverty as the state of households whose total fuel expenditures, particularly on heating services, were in excess of $10 \%$ threshold of their income. Due to "disproportional" nature of that threshold for the poorest percentile of the households (Moore, 2012), the 10 percent of income threshold was adopted for the amount of fuel needed to heat households' homes in the United Kingdom as of $1991^{1}$. In this context, mathematically, households who spend more than $10 \%$ of their income on fuel services in order to maintain the adequate warmth are considered as fuel poor. In the literature, the "adequate warmth" level is defined as $18^{\circ} \mathrm{C}$ in the bedrooms and $20-21{ }^{\circ} \mathrm{C}$ in the living room with reference to the World Health Organization (Boardman, 2010).

One of the definitions of energy poverty is that "one measure of energy poverty at the level of the poorest is the inability to cook with modern cooking fuels and the lack of a bare minimum of electric lighting to read, or for other household and productive activities after sunset. These minimum needs correspond to about 50 kilograms of oil equivalent

1 For various suggestion regarding the government's update on $10 \%$ threshold value in the UK and the use of different variables in determinig energy poverty; J. Hills (2012) "Getting the Measure of Fuel Poverty” CASE Report 72, Centre for Analysis of Social Exclusion: London. 
$\left(\right.$ kgoe $\left.^{2}\right)$ of annual commercial energy per capita; this estimate is based on the need for approximately $40 \mathrm{kgoe}$ per capita for cooking and $10 \mathrm{kgoe}$ used as fuel for electricity" (Modi et al. 2005, 9).

In this context, the definition does not only cover agriculture, transportation, communication and similar social activities by focusing on the household's basic energy needs such as cooking and lighting (Modi et al. 2005: 9-10). According to another definition, "A person is in 'energy poverty' if they do not have access to at least: (a) the equivalent of $35 \mathrm{~kg}$ LPG for cooking per capita per year from liquid and/or gas fuels or from improved supply of solid fuel sources and improved (efficient and clean) cook stoves and (b) 120kWh electricity per capita per year for lighting, access to most basic services (drinking water, communication, improved health services, education improved services and others) plus some added value to local production" (Tennakoon, 2008: 6).

Pye et al. (2015) defined energy poverty as a situation in which individuals are unable to heat their homes (or failure in meeting the necessary energy services) at affordable costs and stated that the problem could be characterized by the following three key drivers in either combination or isolation: existence of either of the following three important substances are single or together: (i) Low incomes, (ii) Poor thermal efficiency of buildings and (iii) High energy costs. Thus, energy poverty in the literature can be summarized as not being able to attain or not be able to use the energy required to sustain basic vital needs.

Energy poverty does not only apply to developing or underdeveloped countries. Similarly, in developed countries, low-income segments are included in energy poverty. Upon estimation on the basis of spending size by taking into account the spending expenditure of more than $10 \%$ of household income in developed countries, and also according to the results of the survey conducted on whether or not the households can keep their houses warm enough, 200 million people in developed countries (more than 15\% of the total population of the entire developed countries) are expected to face an energy poverty problem (IEA, 2017b: 24).

Especially for the United Kingdom, this issue has been investigated for a long time, and there are many studies on this subject. In 2011, approximately 4.5 million households in the UK were determined to be energy-poor using a definition of $10 \%$. Northern Ireland is the country with the largest proportion of poor households among the four countries of the United Kingdom (Preston et al., 2014: 5). Nevertheless, it is known that $45 \%$ of families with children, $21 \%$ of the couples and $25 \%$ of the adults living alone are fuel-poor (JRF, 2017). According to the EU Revenue and Living Conditions Statistics, $10.2 \%$ of the European population cannot keep their homes warm enough. Other data indicate high levels

2 Kgoe is a standardized unit which is assigned to measure the energy from different sources by conversion into oil equivalent (Modi et al. 2005: 9). 
of energy poverty, particularly in certain parts of Europe, including Middle East Europe and Southern Europe (Rademaekers et al., 2016: 7).

In the European Union, there is no officially accepted definition, but it takes the energy required for basic services such as a good standard of living and adequate heating, lighting and electrical equipment into consideration to ensure the health of its citizens. Thus, energy-poor households cannot utilize the basic energy services adequately; due to high energy expenditure, low household income, ineffective building structures and equipment, and specific energy requirements. Accordingly, it is estimated that 50 million households in the EU suffer from this poverty (EU, 2018).

\section{Literature Review}

While there is a large body of literature on the definition and measurement of poverty, there is no methodological consensus on the definition and measurement of energy poverty (Barnes, 2011; Rademaekers et al., 2016). In this context, various approaches have been proposed in the literature to define and measure energy poverty. These approaches usually refer to a threshold value that is determined on a physical or expenditure basis defining those below this threshold as energy-poor. Accordingly, a minimum level of physical energy demand is estimated based on the minimum energy requirement for basic needs such as cooking, lighting, and heating. For example, the monthly minimum energy requirement for the rural areas of Bangladesh was $27.1 \mathrm{kgOE}$ and $32.1 \mathrm{kgOE}$ according to Bravo et al. (1979) and Goldemberg (1990), respectively.

Pereira et al. (2011) utilized inequality indicators such as Gini Coefficient and Sen Index in their empirical study which was conducted on the impact of the development of rural electrical services by the public sector in Brazil on energy poverty. According to the study, which takes into account the daily energy demands of the households such as heating, lighting, and cooking, the improvements in electricity access in rural areas significantly reduce energy poverty. Lenz and Grgurev (2017) investigated the energy poverty in new member candidates of the European Union; namely, Bulgaria, Croatia, and Romania. According to the study, in which households with energy expenditures exceeding $10 \%$ of the household expenditures are defined as energy-poor, the ratio of energy-poor households has increased in all three countries over the period from 2009 to 2014 . Nonetheless, the ratios of those who have experienced heating problems in their households are determined as $45 \%$ in Bulgaria, $14 \%$ in Romania and $10 \%$ in Croatia.

Alkon et al. (2016) examined household energy expenditures and access to energy for developing countries, India in particular, over the period from 1987 to 2010. According to the statistical study, which highlighted that households' energy expenditures have a significant share in total expenditures, it is stated that households are willing to consume modern energy facilities such as LPG and electricity if they have access. According to the study, it was determined that energy expenditures are increased if the Indian households increase their access to energy services and it could not be explained by an increase in income. 
Barnes et al. (2011) analyzed energy poverty in rural Bangladesh. Although energy poverty has been described with an energy poverty line indicating physical energy needs such as cooking and lighting for the last twenty years in the literature, their study used a demand-oriented poverty definition. Accordingly, as household income increases, demand for energy also increases and the energy poverty line is determined by a certain percentage of household income. The households, whose income levels are on or below this line, finance their energy expenditures with difficulty, therefore are referred to as energy-poor. According to the empirical analysis carried out by using the cross-sectional data of 2004 for the rural areas of Bangladesh, $45 \%$ of the households in rural areas are income-poor while $58 \%$ are energy-poor.

Ozcan et al. (2013) investigated the economic and demographic factors that influence the energy use of households in Turkey. In the study, where the households' budget survey questionnaire data was used, the energy preferences of households were estimated via the multidimensional logit model. The most important finding of the study asserted that monthly household income or household welfare has a significant impact on energy preferences in general. On the other hand, it was stated that the age level of the individuals also has an impact on the energy preference. In the settlement area, however, it was determined that residents prefer natural gas while rural residents prefer conventional fuels. In Emec et al. (2015), which matched the energy poverty and energy consumption preference profile in Turkey, the factors determining households' energy choices were examined. In this context, energy preferences such as wood, coal, electricity, natural gas, dung and similar are analyzed according to demographic characteristics on the rural-urban basis. According to the study using the 2012 Household Budget Survey data set, it is determined that the fuel preferences of the households with low levels of education have less preference on modern energy facilities such as natural gas and electricity, which require more expensive infrastructures than others. It is emphasized that poor households consume more wood and coal in both rural and urban settlements, respectively.

Pachauri et al. (2004) discussed the measurement of household energy poverty in India. In the study, which examined energy and poverty together, a short evaluation of different energy poverty measurement methods is presented. In the study, the household data set of 1983-2000 was used, and it was determined that the rapid development process significantly decrease energy poverty. Sadath and Acharya (2017) conducted an empirical analysis for India using a multidimensional energy poverty index. According to the results of the study, energy poverty is a very common phenomenon in India. Aristondo and Onaindia (2018) investigated energy poverty in various household groups in Spain. In the study using data from 2005, 2008, 2012 and 2016, households were separated into groups in terms of gender, household type, education, and similar characteristics and inequality were examined separately for each group. Accordingly, energy poverty indicators in Spain have deteriorated even more from 2005 to 2016. It was found that the deterioration has been particularly specific for the population outside of Europe. Papada and Kaliampakos (2016) estimated energy poverty for Greece. According to the results of the study using the estimation method based on expenditure, 58\% of Greek households are energy-poor. Energy 
poverty exceeds $90 \%$ in households below the poverty line. However, it has been determined that households have cut down on various basic needs to tackle energy poverty.

\section{Descriptive Statistics}

The literature asserts the existence of a close relationship between energy use and economic development. Variables such as energy/electricity consumption, the number of vehicles and $\mathrm{CO}_{2}$ emissions are generally included among the basic macroeconomic indicators of a country. For instance, Germany and the United States have the same scores in the Human Development Index (0.92), as well as they tend to converge in life expectancy ( 80 and 78, respectively), and they both have high energy consumption levels (Eguino, 2015). In this context, the impacts of energy use on education and health indicators are also examined extensively in the literature (Sovacool et al., 2012; Bridge, 2017; Tod \& Thomson, 2016; Mzavanadze, 2018; Liddell \& Morris, 2010; Bouzarovski \& Petrova, 2015). Table 1 indicates the electricity consumption and energy usage data regarding various countries of the upper-middle income bracket including Turkey along with EU averages over the years from 1990 to 2014.

\section{Table: 1}

\section{Electricity Consumption and Energy Use Per Capita in Selected Countries}

\begin{tabular}{|c|c|c|c|c|}
\hline \multicolumn{5}{|c|}{ Electricity Consumption (kWh per capita) } \\
\hline & 1990 & 2000 & 2010 & 2014 \\
\hline Bosnia and Herzegovina & 2.937 & 2.021 & 3.141 & 3.365 \\
\hline Brazil & 1.457 & 1.891 & 2.361 & 2.601 \\
\hline Chile & 1.240 & 2.512 & 3.320 & 3.911 \\
\hline Colombia & 841 & 829 & 1.077 & 1.289 \\
\hline Mexico & 1.165 & 1.750 & 1.963 & 2.090 \\
\hline Russian Federation & 6.673 & 5.198 & 6.409 & 6.602 \\
\hline Serbia & 4.628 & 4.198 & 4.358 & 4.271 \\
\hline Turkey & 929 & 1.652 & 2.491 & 2.854 \\
\hline EU & 5.157 & 5.821 & 6.268 & 5.908 \\
\hline Upper-Middle Income & 1.352 & 1.584 & 2.912 & 3.516 \\
\hline \multicolumn{5}{|c|}{ Energy Use (oil, kg per capita) } \\
\hline Bosnia and Herzegovina & 1.572 & 1.153 & 1.741 & 2.194 \\
\hline Brazil & 938 & 1.069 & 1.351 & 1.484 \\
\hline Chile & 1.057 & 1.648 & 1.815 & 2.049 \\
\hline Colombia & 706 & 638 & 679 & 711 \\
\hline Mexico & 1.448 & 1.474 & 1.489 & 1.513 \\
\hline Russian Federation & 5.928 & 4.224 & 4.819 & 4.942 \\
\hline Serbia & 2.598 & 1.826 & 2.141 & 1.859 \\
\hline Turkey & 977 & 1.201 & 1.474 & 1.577 \\
\hline EU & 3.441 & 3.472 & 3.420 & 3.079 \\
\hline Upper-Middle Income & 1.368 & 1.288 & 2.011 & 2.204 \\
\hline
\end{tabular}

Source: World Bank Development Indicator, 2017.

As seen in Table 1, electricity consumption per capita in the surveyed countries over the period from 1990 to 2014 has an upward trend, while it is almost constant in Russia. In particular, the increase in the electricity-accessible population (WB, 2017), also reveals itself in electricity consumption. The levels of electricity consumption per capita in the European Union and Russia were quite high as of 1990 while electricity consumption in Colombia and Turkey were quite low. Finally, while the whole population in Turkey had access to electricity, power and energy consumption per capita was lower than the mean value of the upper-middle income countries by 2014. The share of renewable energy in the total energy consumption in Turkey was $24.5 \%$ in 1990 , and it decreased to $11.6 \%$ as of 2014 (Table 2). 
In this context, the decrease in the share of renewable sources in energy consumption is closely associated with energy poverty.

Table: 2

Renewable Energy Consumption in Selected Countries (\% of Total Final Energy Consumption)

\begin{tabular}{|c|c|c|c|c|}
\hline & 1990 & 2000 & 2010 & 2014 \\
\hline Bosnia and Herzegovina & 7.30 & 19.35 & 19.56 & 41.74 \\
\hline Brazil & 49.86 & 42.79 & 47 & 41.84 \\
\hline Chile & 34.02 & 31.36 & 27.04 & 26.71 \\
\hline Colombia & 38.25 & 28.02 & 27.93 & 24.44 \\
\hline Mexico & 14.41 & 12.16 & 9.35 & 9.75 \\
\hline Russian Federation & 3.75 & 3.49 & 3.34 & 3.42 \\
\hline Serbia & 15.49 & 23.58 & 20.59 & 23.42 \\
\hline Turkey & 24.51 & 17.26 & 14.32 & 11.60 \\
\hline EU & 6.12 & 7.92 & 12.96 & 16.22 \\
\hline Upper-Middle Income & 19.13 & 19.99 & 13.66 & 14.03 \\
\hline
\end{tabular}

Source: World Bank Development Indicator, 2017.

The energy use possibilities of the households in Turkey are shown in Table 3. The data of the years 2003 and 2017 include the heating systems of the households, the types of fuel they used, the piped water system and the natural gas subscriptions. According to this, $75 \%$ of households in 2003 were heated by a stove, $8.37 \%$ by common or central heating, and $13.63 \%$ by floor heater/combination boiler. Therefore, it is seen that wood and coal were intensively used fuel types. The rate of natural gas use was approximately $17 \%$.

Table: 3

Household Energy Usage in Turkey, 2003-2017

\begin{tabular}{|c|c|c|c|}
\hline \multicolumn{2}{|l|}{2003} & \multicolumn{2}{|c|}{2017} \\
\hline \multicolumn{4}{|c|}{ Heating System (\%) } \\
\hline Stove & 75.70 & Stove & 37.14 \\
\hline Common or Central Heating & 8.37 & Common or Central Heating & 11.73 \\
\hline Floor Heater / Combination Boiler & 13.63 & Floor Heater / Combination Boiler & 41.64 \\
\hline Other & 2.30 & Air Conditioning & 3.99 \\
\hline & & Other & 0.02 \\
\hline \multicolumn{4}{|c|}{ Fuel Type (\%) } \\
\hline Wood & 54.64 & Wood & 28.59 \\
\hline Coal & 18.70 & Coal & 13.37 \\
\hline Natural Gas & 16.92 & Natural Gas & 49.07 \\
\hline Fuel-Oil & 0.55 & \begin{tabular}{|l|} 
Fuel-Oil \\
\end{tabular} & 0.20 \\
\hline Diesel & 0.57 & Thermal & 0.57 \\
\hline Kerosine & 0.07 & Solar & 0.02 \\
\hline LPG & 0.41 & LPG & 0.08 \\
\hline Electricity & 3.98 & Electricity & 6.68 \\
\hline Dung & 2.68 & Dung & 1.26 \\
\hline Other & 1.48 & Other & 0.14 \\
\hline \multicolumn{4}{|c|}{ Piped Water System (\%) } \\
\hline Yes & 96.64 & Yes & 99.65 \\
\hline No & 3.36 & No & 0.35 \\
\hline \multicolumn{4}{|c|}{ Natural Gas (\%) } \\
\hline Yes & 17.60 & Yes & 50.80 \\
\hline No & 82.40 & No & 49.20 \\
\hline
\end{tabular}

Source: Household Budget Survey Data Set, 2003-2017.

In 2017, however, the rate of stove use in the heating system of the households decreased to $37.14 \%$. The most important reason for this is that the prevalence of natural gas subscriptions approached $49 \%$ and became widespread. In this context, the rate of floor heating or boiler use was $42 \%$. Similarly, the use of such fuel types such as wood and coal 
decreased. The increase in the use of electricity as a fuel type is another remarkable point in the table. The rate of use of electricity, which was around $4 \%$ in 2003 , increased up to $6.68 \%$ as of 2017. Therefore, an increase in natural gas usage is seen from 2003 to 2017 along with access to natural gas. Table 4 indicates the sources of hot water and cooking fuel types used by the households in Turkey over the years from 2009 to 2017. According to the table, the use of natural gas for cooking and hot water has increased over the years. Another important point is the increase in the use of solar energy for hot water. Accordingly, solar energy is third in row as the fuel type with $22.24 \%$ for hot water.

Table: 4

Cooking and Hot Water Fuel Types in Turkey, 2009-2017

\begin{tabular}{|c|c|c|c|}
\hline \multicolumn{2}{|c|}{2009} & \multicolumn{2}{|c|}{2017} \\
\hline \multicolumn{4}{|c|}{ Cooking Fuel Type } \\
\hline Wood & 2.81 & Wood & 1.89 \\
\hline Coal & 0.22 & Coal & 0.31 \\
\hline Dung & 1.13 & Dung & 0.75 \\
\hline Fuel-Oil & 0.01 & Fuel-Oil & 0.01 \\
\hline Natural Gas & 23.61 & Natural Gas & 48.28 \\
\hline LPG & 71.16 & LPG & 47.77 \\
\hline Electricity & 0.87 & Electricity & 0.95 \\
\hline Other & & Other & 0.04 \\
\hline \multicolumn{4}{|c|}{ Hot Water Fuel Type } \\
\hline Wood & 10.34 & Wood & 3.12 \\
\hline Coal & 1.76 & Coal & 0.97 \\
\hline Dung & 1.80 & Dung & 0.55 \\
\hline Fuel-Oil & 0.06 & Fuel-Oil & 0.10 \\
\hline Natural Gas & 21.49 & Natural Gas & 46.88 \\
\hline LPG & 13.77 & LPG & 2.89 \\
\hline Electricity & 31.97 & Electricity & 22.82 \\
\hline Diesel & 0.05 & Solar & 22.24 \\
\hline Kerosine & 0.01 & Thermal & 0.37 \\
\hline Other & 18.76 & Other & 0.05 \\
\hline
\end{tabular}

Source: Household Budget Survey Data Set, 2009-2017.

The energy poverty indicators over the years from 2006 to 2017 in Turkey are indicated in Table 5. Accordingly, the ratio of households who could not pay electricity, water and gas bills as they planned within the last twelve months in 2006 was 25\%, and it became $24.2 \%$ in 2016 . Approximately $74.5 \%$ of the households reported that they did not face any problems with the payments. In 2006, the ratio of households that could afford the heating costs was $64 \%$. However, it went up to $77.7 \%$ as of 2016 . Therefore, it can be said that the majority of households do not encounter any problems in the financing of heating systems. However, $82.5 \%$ of the households reported that they had difficulty in affording required expenditures with their total income in 2006, and it went down to 68\% by 2016. Similarly, upon considering all expenditures related to housing, the ratio of those who stated that these expenditures impose a burden on the household was $87.73 \%$ in 2006, and it reduced to $75.33 \%$ in 2016 . In this context, it can be asserted that basic energy poverty indicators of the households attain a certain degree of improvement. 
Table: 5

Household Energy Poverty Indicators in Turkey, 2006-2016

\begin{tabular}{|c|c|c|c|}
\hline \multicolumn{2}{|l|}{2006} & \multicolumn{2}{|c|}{2016} \\
\hline \multicolumn{4}{|c|}{ The Ratio of Households Who Could Not Pay Electricity, Water and Gas Bills as They Planned Within the Last 12 Months } \\
\hline 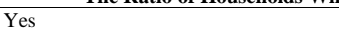 & 25.13 & Yes & 24.20 \\
\hline No & 74.61 & No & 74.62 \\
\hline No Payment of this type & 0.26 & No Payment of this type & 1.18 \\
\hline \multicolumn{4}{|c|}{ The Ratio of Households That Could Afford the Heating Costs } \\
\hline Yes & 64.09 & Yes & 77.69 \\
\hline No & 35.91 & No & 22.31 \\
\hline \multicolumn{4}{|c|}{ Total Income of Household and Situation in Which Can Be Made Necessary Expenditures } \\
\hline Much Difficult & 24.70 & Much Difficult & 6.25 \\
\hline Difficult & 31.02 & Difficult & 25.20 \\
\hline A Little Difficult & 26.87 & A Little Difficult & 36.46 \\
\hline Slightly Easy & 10.34 & Slightly Easy & 20.46 \\
\hline Easy & 6.40 & Easy & 10.92 \\
\hline Very Easy & 0.67 & Very Easy & 0.70 \\
\hline \multicolumn{4}{|c|}{ Considering All the Expenses That Are Made in Relation to Housing, How These Costs Bring a Burden to the Household } \\
\hline Much Burden & 36.89 & Much Burden & 16 \\
\hline A Little Burden & 50.84 & A Little Burden & 59.33 \\
\hline Not Burden & 12.27 & Not Burden & 24.67 \\
\hline
\end{tabular}

Source: Surveys on Income and Living Conditions, 2006-2016

\section{Profiles of Energy-Poor Households in Turkey}

In this section, energy poverty in Turkey is calculated by using the definition of "if a household spends more than $10 \%$ of their income on energy to heat up sufficiently, it is energy poor" and is examined by the socio-economic characteristics of these households. For this purpose, TURKSTAT household budget surveys are utilized and all energy consumption of households (all variables starting with 45 in the consumption data set) are divided into monthly expenditure and monthly usable income. If this rate is more than $10 \%$, that household is considered as energy poor. Although we observe a decrease in energy poverty of households from the survey data in 2003 and the most up-to-date in 2017, approximately one quarter of households still face the problem of energy poverty.

Table: 6

Energy-Poor Households by Years

\begin{tabular}{|c|c|c|}
\hline Years & By Monthly Expenditure & Monthly Average Usable Income \\
\hline 2003 & $36.40 \%$ & $30.49 \%$ \\
\hline 2017 & $23.32 \%$ & $18.38 \%$ \\
\hline
\end{tabular}

Sources: Household Budget Survey Data Set, 2003-2017.

In the following parts of the analysis, only households whose monthly energy consumption is more than $10 \%$ compared to monthly expenditure is examined and monthly expenditure is actually used as a proxy of income because energy consumption is a variable reported monthly, so it is preferred to use a monthly calculated variable as the explanatory variable and it is not preferred to convert annual usable income into salaries. Another reason is that the data in the questionnaire is completely recorded according to the declaration of the household and the household members are asked for the income of that month, but it is not preferred to match the monthly consumption data of the household by using the household data, which may be generating unstable monthly incomes if the person is working as a seasonal worker or tradesman. In other words, household spending has been used by assuming that spreading household spending from time to time makes flattens expenditure. 
When the five groups are examined according to the expenditure groups, as expected, while the most energy-poor households belong to the lowest expenditure/income level, another point observed is that the last group which has the highest expenditure and the highest income includes energy-poor households. However, a remarkable point here is the decrease in all groups especially from the last group in 2003 to 2017. In the fifth group, which has the highest income level in 2003, the share of energy-poor households decreased from $25 \%$ to $3 \%$ in 2017. In the fifth group, which has the highest income level in 2003, the share of energy-poor households decreased from $25 \%$ to $3 \%$ in 2017 . Therefore, there is a significant improvement for the highest groups, while the improvement for the poorest groups is rather low.

\section{Table: 7}

Energy Poverty by Expenditure Groups

\begin{tabular}{|c|c|c|c|c|c|}
\hline Years & First Group & Second Group & Third Group & Fourth Group & Fifth Group \\
\hline 2003 & $48.96 \%$ & $41.99 \%$ & $33.69 \%$ & $31.81 \%$ & $25.53 \%$ \\
\hline 2017 & $46.24 \%$ & $31.93 \%$ & $23.21 \%$ & $11.73 \%$ & $3.48 \%$ \\
\hline
\end{tabular}

Source: Household Budget Survey Data Set, 2003-2017.

\section{Table: 8}

\section{Characteristics and Habits of Energy-Poor Households}

\begin{tabular}{|c|c|c|c|c|}
\hline \multirow[t]{2}{*}{ Characteristics of Household } & \multicolumn{2}{|c|}{$2003(\%)$} & \multicolumn{2}{|c|}{2017} \\
\hline & Yes & No & Yes & No \\
\hline Toilet & 88.59 & 11.41 & 89.68 & 10.32 \\
\hline Bathroom & 94.07 & 5.93 & 97.09 & 2.91 \\
\hline Kitchen & 96.20 & 3.80 & 98.75 & 1.25 \\
\hline Combination Boiler & 17.95 & 82.05 & 37.19 & 62.81 \\
\hline Floor Heater & 0.08 & 99.92 & 0.52 & 99.48 \\
\hline Natural Gas & 7.78 & 92.22 & 28.01 & 71.99 \\
\hline Hot Water & 51.48 & 48.52 & 88.54 & 11.46 \\
\hline Field Ownership & 19.72 & 80.28 & 28.82 & 71.18 \\
\hline Vineyard & 8.48 & 91.52 & 15.89 & 84.11 \\
\hline Land & 2.15 & 97.85 & 3.58 & 96.42 \\
\hline Shop & 3.80 & 96.20 & 4.17 & 95.83 \\
\hline Habit of Smoking & 51.34 & 48.66 & 42.46 & 57.54 \\
\hline Habit of Alcohol & 4.11 & 95.89 & 2.88 & 97.12 \\
\hline Habit of Eating Out & 12.28 & 87.72 & 17.58 & 82.42 \\
\hline Habit of Going to Coffeehouse (Kahvehane) & 20.98 & 79.02 & 20.72 & 79.28 \\
\hline Use of Credit Card & 19.33 & 80.67 & 34.72 & 65.28 \\
\hline Property of House & 72.58 & 27.42 & 65.72 & 34.28 \\
\hline Housing Dept & 49.02 & 50.98 & 10.26 & 89.74 \\
\hline
\end{tabular}

When the conditions under which the energy-poor households live are examined, it is possible to reach similar results both in 2003 and 2017. Approximately $10 \%$ of the households do not have toilets, although bathrooms are available in most households. At this point, it should be noted that both the bathroom and the toilet were marked as present when the bathroom and toilet were in the same place, but the toilet was considered to be absent if the toilet owned was outside the residence. Therefore, this indicates that some of the energypoor households live in rural areas. A result of the characteristics of energy-poor households is observed both in 2003 and 2017. Most of the energy-poor households do not have floor heaters, which indicates that the use of stoves in these households are widespread. When the household habits are examined, it is observed that the habit of eating out at lunch or dinner in the household increased significantly by 2017. This indicates that there are individuals working in the household, but still face energy poverty. In one fifth of the households, there is an individual who has the habit of going to coffeehouses in the household and this ratio 
has not changed over the years. Interestingly, the habit of using credit cards increased among energy-poor households over the years, but the debt of the household decreased. However, when the explanations of the 2017 survey are examined, it is stated that the housing is recorded as having a debt payment or a bank debt during the survey period, but in 2003 the household was asked the question of whether they had debts or installments. The reason for this significant decrease is thought to be the way of questioning.

When the property is examined, it is observed that the percentage of households considered as energy poor have a decrease in their housing. When this decrease is examined in detail, the option of "does not own a house but does not pay housing rent" stands out, in which households live in their father's house, relative's house, etc. without paying any price or paying a very low value below the market price. While the rate of those who did not own a house and did not pay housing rent increased from $4.31 \%$ in 2003 to $14.85 \%$ in 2017 , the ratio of those who stated that they live in rent decreased from 21.95 to 18.72 .

The options for the question of the type of Energy Poor Households do not fully coincide between 2003 and 2017, but it is possible to make a comparison in general terms. The highest type of energy-poor households is the nuclear family without children with $15.45 \%$. Energy-poor households following this type of household are nuclear families with two children (14.05\%), all of whom are younger than the age of 18, nuclear families with three or more children $(10.35 \%)$, all of whom are younger than 18 , and single children (10.13\%). In 2017, similar to 2003, couples without children were the highest energy-poor households with $25.18 \%$, followed by a single adult family with $19.13 \%$ and patriarchal or extended families with 17.77\%. Similarly, in the 2003 and 2017 surveys, although the options for housing types were different, in $2003,50.7 \%$ of the energy-poor households stated that they lived in detached houses, while $2.81 \%$ stated that they lived in squatter settlements. In 2017, the share of households with energy-poor living in detached houses is $60.38 \%$. In 2017, there is no separate an option for squatter settlements.

Table: 9

Primary Fuel Used by Energy-Poor Households (\%)

\begin{tabular}{|l|c|c|}
\hline & $\mathbf{2 0 0 3}$ & $\mathbf{2 0 1 7}$ \\
\hline Wood & 74.77 & 46.74 \\
\hline Coal & 10.59 & 20.95 \\
\hline Natural Gas & 7.44 & 26.89 \\
\hline Electricity & 1.31 & 3.47 \\
\hline Dung & 1.22 & 1.04 \\
\hline LPG & 1.37 & 0.07 \\
\hline Fuel Oil & 1.83 & 0.04 \\
\hline
\end{tabular}

When the data is examined, the number of people stating that they use stoves to heat the house is $72.58 \%$ in 2003 , whereas this rate is $68.98 \%$ in 2017 . Therefore, despite the 14 years and the widespread use of natural gas, most of the energy-poor households are still heated by stoves, including the natural gas stove. This is also evident when the primary fuel type used by energy-poor households is examined. Despite the widespread use of natural gas in 2017, many households prefer to use wood as their primary fuel, just as in 2003. Another remarkable result compared to 2003 is the increased use of coal in energy-poor households. As it is known, coal is one of the most damaging fossil fuels to nature (Table 3 ). 
Table: 10

Saving Habits of Energy-Poor Households (\%)

\begin{tabular}{|l|c|c|}
\hline & $\mathbf{2 0 0 3}$ & $\mathbf{2 0 1 7}$ \\
\hline Not Saving & 84.51 & 76.52 \\
\hline Bank Account & 1.82 & 5.68 \\
\hline Investment in Business & 2.93 & 5.34 \\
\hline Currency & 4.14 & 0.33 \\
\hline Gold & 3.03 & 2.29 \\
\hline
\end{tabular}

Saving is a very important issue for households because it serves as a buffer against unexpected expenditures and is very important for the return of investment and the growth of the economy. When the question of how energy-poor households evaluate savings is investigated, it is clear that many households do not actually make savings. Although this ratio has decreased from 2003 to 2017, one fourth of energy-poor households still do not/cannot save.

\section{Conclusion}

Countries' desire to produce more goods and services due to economic growth increases the demand for energy in all sectors of the economy. Supporting energy consumption with economic growth as well as population growth leads to various problems regarding energy supply security and consumption. However, despite the increasing demand for energy demand on a global scale, people around the world are still unable to access even the most basic energy resources. According to the International Energy Agency, 1.1 billion people cannot access electricity in 2016 , while 2.8 billion people do not have the opportunity to cook clean food. In the European Union countries, $8.2 \%$ of the population cannot keep a sufficient amount of hot water in their homes and $8.1 \%$ have financial problems in bill payments such as electricity, water and gas. Therefore, the terms of energy poverty, which is referred to as "not being able to access modern energy facilities", has started to be studied intensively in the literature and has become a concept that has been emphasized in the world agenda since it became one of the sustainable development targets in 2015.

The study deals with the energy poverty in Turkey. After the conceptual analysis of energy poverty, data on current energy consumption in various countries are given and indicators related to energy poverty are examined. Elsewhere, determining of characteristics of energy-poor households in Turkey, with the help of the 2017 household budget survey data sets, constitute the unique aspects of the work and contribute to the existing literature.

The most important conclusion of the study, according to data from the 2017 household data, is that about one of a quarter of households are energy-poor in Turkey. Accordingly, about half of the lowest income households face the problem of energy poverty. In the fifth richest households, this ratio is only $3.48 \%$. However, the ratio of energy-poor households decreased from 2003 to 2017. While $36 \%$ of households were energy poor in 2003 , this ratio declined to $23 \%$ in 2017 . Despite the decline, the poorest households have not improved significantly. When the characteristics and habits of energypoor households are examined, it was found that in $2017,72 \%$ had no natural gas, $63 \%$ had no floor heater, $11.5 \%$ had no hot water, and $10.3 \%$ had no toilet. On the other hand, $90 \%$ 
of the households are indebted, $76.5 \%$ do not make savings, 34\% do not have housing ownership and $82 \%$ do not have the habit of eating out.

\section{References}

Alkon, M. \& S. Harish \& J. Urpelainen (2016), "Household Energy Access and Expenditure in Developing Countries: Evidence from India 1987-2010”, Energy for Sustainable Development, 35, 25-34.

Aristondo, O. \& E. Onaindia (2018), "Inequality of Energy Poverty Between Groups in Spain", Energy, 153, 431-442.

Barnes, D. \& S. Khandker \& H.A. Samad (2011), "Energy Poverty in Rural Bangladesh", Energy Policy, 39, 894-904.

Barnes, D. (2010), The Concept of Energy Poverty, <http://www.energyfordevelopment.com/2010/06/energy-poverty.html>, 28.08.2018.

Boardman, B. (1991), Fuel Poverty: From Cold Homes to Affordable Warmth, Belhaven Press: London.

Boardman, B. (2010), Fixing fuel poverty: Challenges and Solutions, Earthscan: London.

Bouzarovski, S. \& S. Petrova (2015), “A Global Perspective on Domestic Energy Deprivation: Overcoming the Energy Poverty- Fuel Poverty Binary", Energy Research \& Social Science, 10, 31-40.

Bravo, V. \& G. Mendoza \& J. Legisa \& C. Suarez \& I. Zyngierman (1979), "Estudio Sobre Requerimientos Futuros No Convencionales de Energia en America Latina", Report to the UNDP.

Bridge, B. (2017), "Individual and Household-Level Effect of Energy Poverty on Human Development", PhD. Dissertation, University of New Mexico.

Buzar, S. (2007), Energy Poverty in Eastern Europe: Hidden Geographies of Deprivation, Abingdon: Routledge.

EC. (2012), Share of Households' Expenditure on Electricity, Gas and Other Housing Fuels, European Commission, <https://ec.europa.eu/energy/en/content/share-householdsexpenditure-electricity-gas-and-other-housing-fuels>, 28.08.2018.

Eguino, M.G. (2015), "Energy Poverty: An Overview”, Renewable and Sustainable Energy Reviews, 47, 377-385.

Emec, H. \& A. Altay \& E. Aslanpay \& M.O. Ozdemir (2015), "Energy Poverty and Energy Choice Profile in Turkey", Finans Politik \& Ekonomik Yorumlar, 52(608), 9-21.

EPEE (2009), Study of Fuel Poverty in Europe, European fuel Poverty and Energy Efficiency, <https://ec.europa.eu/energy/intelligent/projects/en/projects/epee>, 28.08.2018.

EU (2018), Energy Poverty Statistics, EU Energy Poverty Observatory, <https://www.energypoverty.eu/>, 28.08.2018.

EUROSTAT (2018), Statistics Database, <https://ec.europa.eu/eurostat/data/database>, 28.08.2018.

Goldemberg, J. (1990), “One Kilowatt per Capita”, Bulletin of the Atomic Scientists, 46, 12-26.

Hills, J. (2012), "Getting the Measure of Fuel Poverty", Final Report of the Fuel Poverty Review.

Ibitoye, F. (2013), "The Millennium Development Goals and Household Energy Requirements in Nigeria", Springerplus, 2(1), 2-9.

IEA (2017a), Energy Access Outlook 2017: From Poverty to Prosperity, Paris: OECD/IEA. 
IEA (2017b), Renewables 2017: Analysis and Forecasts to 2022, Paris: OECD/IEA.

JRF (2017), “UK Poverty 2017”, Report by the Joseph Rowntree Foundation.

Lenz, N.V. \& I. Grgurev (2017), “Assessment of Energy Poverty in New European Union Member States: The Case of Bulgaria, Crotia and Romania", International Journal of Energy Economics and Policy, 7(2), 1-8.

Lewis, J. (1982), A Three-Part Proposal: Three Stages for Natural Disaster Mitigation Strategy: Intergrated with Socia-Evonomic Development at National, Provincial and Local Levels, The United Nations Environment Programme.

Li, K. \& L. Bob \& X.J. Liang \& Y.M. Wei (2014), "Energy Poor or Fuel Poor: What are the Differences?", Energy Policy, 68, 476-481.

Liddell, C. \& C. Morris (2010), "Fuel Poverty and Human Health: A Review of Recent Evidence", Energy Policy, 38(6), 2987-2997.

Marmot Review Team (2011), The Health Impact of Cold Homes and Fuel Poverty, London: Friends of the Earth \& the Marmot Review Team.

Modi, V. \& S. McDade \& D. Lallement \& J. Saghir (2005), Energy Services for the Millennium Development Goals, Joint publication of the World Bank, Washington DC and the United Nations Development Programme, New York.

Moore, R. (2012), “Definitions of Fuel Poverty: Implications for Policy”, Energy Policy, 49, 19-26.

Mzavanadze, N. (2018), “Quantifying Energy Poverty- Related Health Impacts of Energy Efficiency”, WP5 Social Welfare Final Report.

Nussbaumer, P. (2012), "Energy for Sustainable Development - An Assessment of the Energy Poverty - Development Nexus", Doctoral Thesis, Barcelona: Institute of Environmental Science and Technology.

Ozcan, K.M. \& E. Gülay \& S. Ucdogruk (2013), "Economic and Demographic Determinants of Household Energy Use in Turkey", Energy Policy, 60, 550-557.

Pachauri, S. \& A. Mueller \& A. Kemmler \& D. Spreng (2004), “On Measuring Energy Poverty in Indian Households", World Development, 32(12), 2083-2104.

Papada, L. \& D. Kaliampakos (2016), "Measuring Energy Poverty in Greece”, Energy Policy, 94, 157-165.

Pereira, M.G. \& M. Freitas \& N.F. da Silva (2011), "The Challenge of Energy Poverty: Brazilian Case Study", Energy Policy, 39(1), 167-175.

Practical Action (2008), Energy Poverty: Estimating the Level of Energy Poverty in Sri Lanka, $<$ https://practicalaction.org/docs/region_south_asia/energy-poverty-in-sri-lanka2008.pdf>, 28.08.2018.

Preston, I. \& V. White \& K. Blacklaws (2014), Fuel and Poverty, The Joseph Rowntree Foundation.

Pye, S. \& A. Dobbġns \& C. Baffert \& J. Brajkovġc \& I. Grgurev \& R. De Mġglgo \& P. Deane (2015), Energy Poverty and Vulnerable Consumers in the Energy Sector Across the EU: Analysis of Policies and Measures, Insight-E.

Rademaekers, K. \& J. Yearwood \& A. Ferreira \& S. Pye \& I. Hamil-Ton \& P. Agnolucci \& N. Anisimova (2016), Selecting Indi-cators to Measure Energy Poverty, Rotterdam: European Commission, DG Energy.

Sadath, A. \& R.H. Acharya (2017), "Assessing the Extent and Intensity of Energy Poverty Using Multidimensional Energy Poverty Index: Empirical Evidence from Households in India”, Energy Policy, 12, 540-550. 
Sovacool, B.K. \& C. Cooper \& M. Bazilian \& K. Johnson \& D. Zoppo \& S. Clarke \& J. Eidsness \& M. Crafton \& T. Velumail \& H.A. Raza (2012), "What move sand works: Broadening the Consideration of Energy Poverty", Energy Policy, 42, 715-719.

Tennakoon, D. (2008), Practical Action. Energy Poverty: Estimating the Level of Energy Poverty in Sri Lanka, Colombo: Practical Action South Asia.

Thomson, H. \& S. Bouzarovski (2018), Addressing Energy Poverty in the European Union: State of Play and Action, ENER/B3/SER/2015-507/SI2.742529 Concerning the EU Energy Poverty Observatory, EU Energy Poverty Observatory.

Tod, A. \& H. Thomson (2016), "Health Impacts of Cold Housing and Energy Poverty", in: K. Csiba (ed.), Energy Poverty Handbook, Brussels and Budapest: The European Parliament.

TSI (2016), Surveys on Income and Living Conditions, Micro Data Set.

TSI (2017), Household Budget Survey Data Set.

TSI (2017), Household Budget Survey Newsletter, <http://www.tuik.gov.tr/PreHaberBultenleri.do;jsessionid=x7wgcRyGGh6WWyH2xnK WhN7Z7ZQpKX47Cw5ThkSGh6ffGL4BgLM1!147391579?id=27840>, 28.08.2018.

WB (2018), World Bank Development Indicator.

WB. (2017), World Bank Development Indicator. 